\title{
Removing BOD, COD, and Decolorization of Batik Cual Wastewater using Fenton Mechanism
}

\author{
Rika Favoria Gusa ${ }^{1}$, Diana Novita Sari $^{2}$, Fitri Afriani ${ }^{3}$, Wahri Sunanda ${ }^{4}$, Yuant Tiandho ${ }^{5^{*}}$ \\ ${ }^{1,4}$ Department of Electrical Engineering, Faculty of Engineering, Universitas Bangka Belitung, Indonesia \\ 2,3,5 Department of Physics, Faculty of Engineering, Universitas Bangka Belitung, Indonesia \\ *Corresponding Address: yuanttiandho@gmail.com
}

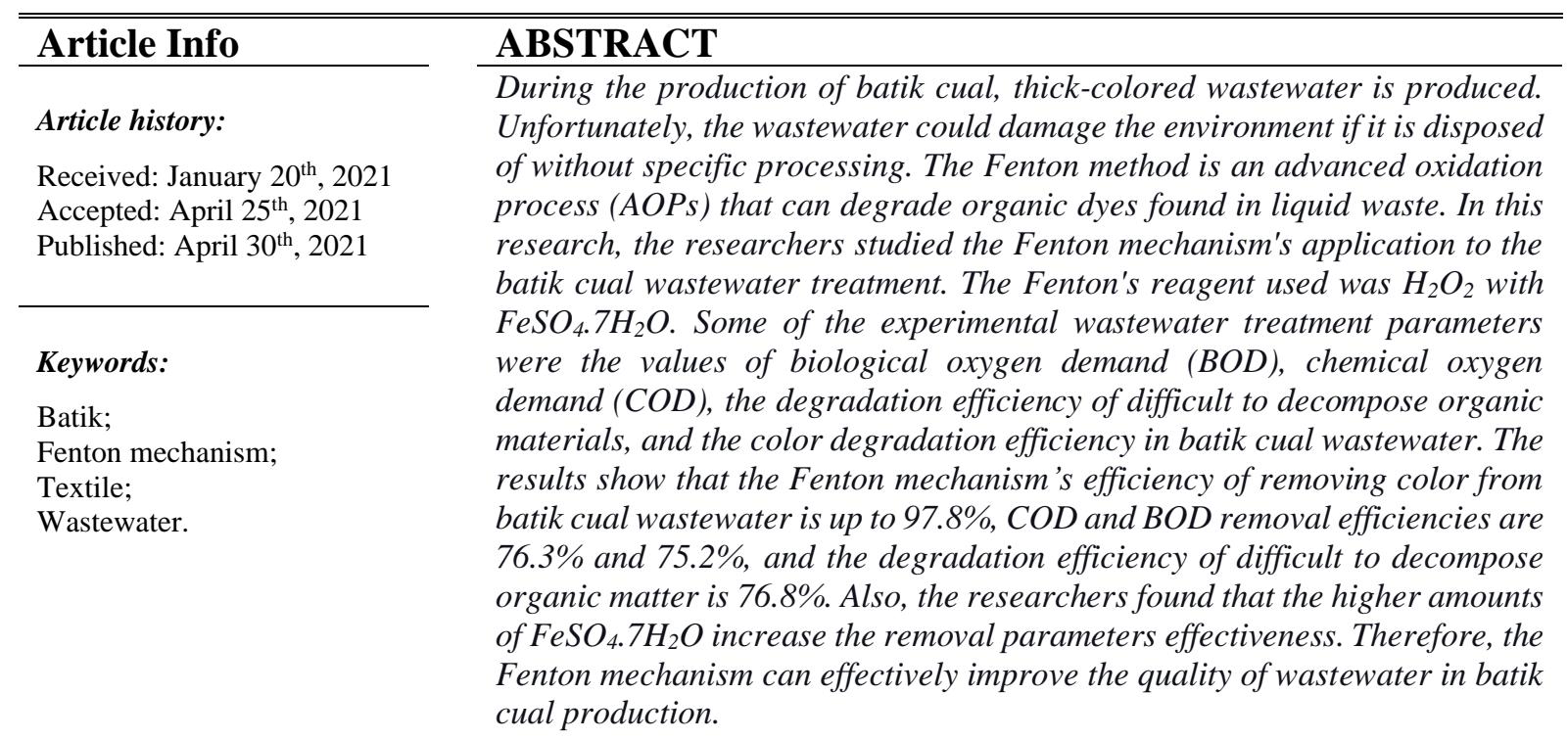

(C) 2021 Physics Education Department, UIN Raden Intan Lampung, Indonesia.

\section{INTRODUCTION}

The cual woven cloth is one of Bangka Belitung's cultural identity products that is often used as a souvenir icon for tourists (Damayanti \& Ferdiana, 2020). Recently, the cual woven fabric artisans are innovating to produce batik-type cual (called as batik cual). This effort is made to reduce production costs so that people can easily purchase the cual. Therefore, the transformation of woven fabrics into batik has made cual famous among tourists and can be applied to various office/school uniforms (Ayan et al., 2018; Tomohardjo et al., 2018).

Besides providing positive values for regional economic growth, the increase in batik cual production harms the environment (Gusa et al., 2020). It can be a severe problem because some batik artisans use synthetic dyes in the production process. The batik synthetic dyes' wastewater will damage the environment because it has high toxicity, is non-biodegradable, and can have carcinogenic and mutagenic properties (Lestari \& Windyartini, 2020; Rahmadyanti \& Febriyanti, 2020). Batik wastewater usually has high color content, chemical oxygen demand (COD), biological oxygen demand (BOD), and some difficult to decompose organic matters (Buthiyappan et al., 2016; Galih et al., 2020; Khalik et al., 2018).

The methods to process textile waste are biological methods (Bhatia et al., 2017; Shoukat et al., 2019), physicochemical methods (adsorption) (Babaei et al., 2017; H. Zhang et al., 2018), coagulation (Dalvand et 
al., 2017; GilPavas et al., 2018) and electrocoagulation (Gusa et al., 2020; Naje et al., 2017). However, these technologies pose several disadvantages. The biological methods require life microorganisms that can only decompose biodegradable compounds. On the other hand, the non-biodegradable compounds will remain in sediment or sludge in the environment (Crini \& Lichtfouse, 2019; Piaskowski et al., 2018). Furthermore, the adsorption method produces waste in adsorbents. This method only removes waste without degrading the waste into harmless compounds (Burakov et al., 2018; Senthil Kumar et al., 2019). Therefore, to solve the complexity of wastewater containing synthetic dyes, the advanced oxidation processes (AOPs) method is currently being developed. It has promising prospects based on strong oxidation performance and can decompose waste pollutants very well (Hassaan \& Nemr, 2017; Paździor et al., 2019). Some of the AOPs techniques often used include the Fenton mechanism (Guo et al., 2018), photo-catalysis (Gilja et al., 2017), $\mathrm{UV} / \mathrm{H}_{2} \mathrm{O}_{2}$ (Malvestiti et al., 2019), and ozonation (Khamparia \& Jaspal, 2017). However, the Fenton mechanism is an attractive alternative technology applied to batik cual wastewater treatment because it can be running at room temperature, decompose harmful non-biodegradable compounds, and does not require additional advanced equipment (M. H. Zhang et al., 2019).

The Fenton mechanism is an oxidation process through Fenton's reagent: $\mathrm{H}_{2} \mathrm{O}_{2}$ and a source of $\mathrm{Fe}$ ions (usually $\mathrm{Fe}^{2+}$ or $\mathrm{Fe}^{3+}$ ion). $\mathrm{Fe}$ ion will act as a catalytic agent while $\mathrm{H}_{2} \mathrm{O}_{2}$ will act as an oxidizing agent. The oxidation process that runs in the Fenton mechanism is classified as a robust oxidation process to degrade organic contaminants (Ghernaout et al., 2020).

Several previous researchers have carried out the application of the Fenton method in degrading batik wastewater. However, most of these studies only use a single type of dye from batik and only focus on reducing the wastewater color (Qin et al., 2018; Setyaningtyas et al., 2019). In practice, batik wastewater contains complex dyes. Also, BOD and COD problems need to be solved besides the color problems.

In this research, the Fenton mechanism in real batik cual wastewater was investigated. Several parameters observed were BOD, COD, the number of organic compounds that were difficult to decompose, and the color concentration. The Fenton mechanism's performance is highly dependent on the amount of reagent used in the oxidation process. Therefore, the researchers investigated Fenton's reagent amount in degrading pollutants. This research aims to provide information regarding the effective dosage of Fenton's reagent in batik cual wastewater treatment.

\section{METHOD}

Batik cual wastewater used in this study was taken from cual batik artisan in Pangkalpinang City, Bangka Belitung Islands. In one production, batik cual artisans can produce about 20 liters of wastewater. To treat batik cual wastewater, the researchers used the Fenton method. The Fenton method was carried out by mixing $100 \mathrm{ml}$ of batik cual wastewater with Fenton's reagent consisting of $1 \mathrm{ml}$ of hydrogen peroxide $\left(\mathrm{H}_{2} \mathrm{O}_{2}\right)$ and $\mathrm{FeSO}_{4} .7 \mathrm{H}_{2} \mathrm{O}$ with mass variations of $\mathrm{FeSO}_{4} .7 \mathrm{H}_{2} \mathrm{O}$ ranging from 0.1 , $0.2,0.3,0.4$, up to 0.5 grams. The oxidation process using the Fenton method was carried out for 24 hours and continued with the measurement of BOD, COD, the number of organic compounds that were difficult to decompose, and the concentration of residual wastewater's color. The BOD value is determined by the difference between the dissolved oxygen on the first day of incubation (DO $i$ ) and the dissolved oxygen after five days of incubation (DO5). The dissolved oxygen measurement was carried out with a DO-meter. COD measurements were carried out using the digestion reactor method. Digestion solution and sulfuric acid are mixed into the sample and then heated in 
the digestion reactor. The COD concentration was determined using a UVVis spectrophotometer (HACH DR 2600) based on a calibration curve at a wavelength of $600 \mathrm{~nm}$. The UV-Vis spectrophotometer was used to measure the color concentration of the sample. The measurement process began by creating a calibration curve determined from the absorbance value at the wavelength that can produce the highest absorbance peak for the standard solution. Furthermore, the absorbance of the sample is measured at this wavelength and the color concentration value is calculated based on the resulting calibration curve (Nandiyanto et al., 2018). The method schematic of this research is shown in Figure 1.

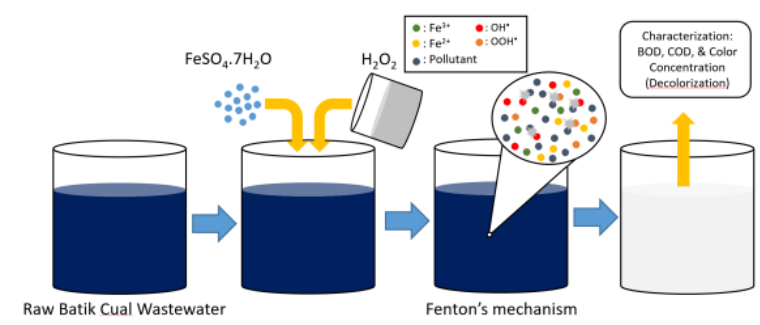

Figure 1. Schematic of the Research Method

\section{RESULTS AND DISCUSSION}

In Figure 2, a comparison between batik cual wastewater and standard freshwater is presented. Batik cual wastewater is dark bluish-purple color because various synthetic dyes are used, such as remazol, naphthol, or indigosol. Therefore, if batik cual wastewater is disposed of in the aquatic environment, it will disturb the organisms because it blocks sunlight for the photosynthesis process.

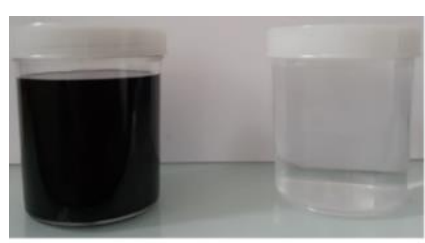

(a)

(b)

Figure 2. The Comparison between: (a) Batik Cual Wastewater; (b) Standard Freshwater

After the Fenton mechanism was carried out using the $\mathrm{H}_{2} \mathrm{O}_{2}$ reagent with variations in the amount of $\mathrm{FeSO}_{4} .7 \mathrm{H}_{2} \mathrm{O}$ for 24 hours, various transformation of batik cual wastewater occur as shown in Figure 3. After the Fenton treatment, batik cual wastewater has a more transparent color. The decolorization process occurred from initially dark bluish-purple to bluish-purple. With the Fenton treatment with 0.5 gr of $\mathrm{FeSO}_{4} .7 \mathrm{H}_{2} \mathrm{O}$ reagent, the wastewater has become more transparent, almost like a standard freshwater. It shows that the Fenton mechanism is effective for decolorizing batik cual wastewater. The more $\mathrm{FeSO}_{4} .7 \mathrm{H}_{2} \mathrm{O}$ used in Fenton treatment, the more significant the decolorization process will be.

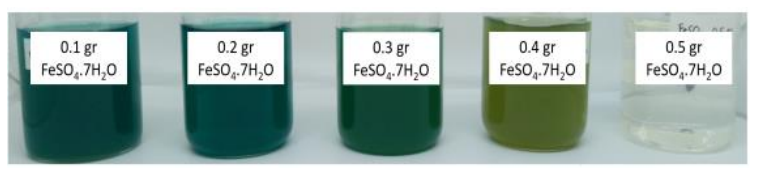

Figure 3. The Results of the Fenton Mechanism in Batik Cual Wastewater Based on Mass Variations of $\mathrm{FeSO}_{4} .7 \mathrm{H}_{2} \mathrm{O}$

The decolorization process of batik cual wastewater through the Fenton mechanism occurred due to the formation of free radicals such as $\mathrm{HO}^{\circ}$ (hydroxyl radicals) and $\mathrm{HO}_{2}{ }^{\circ}$ (hydroperoxyl radicals) during the Fenton oxidation process. Hydroxyl radical is an oxidizing agent with an electrochemical oxidation potential value up to $2.80 \mathrm{~V}$. This value is higher than other oxidizing agents such as ozone $(2.08 \mathrm{~V})$, hypochlorite (1.49 $\mathrm{V})$, and chlorine (1.36 V) (Hassaan \& Nemr, 2017). The formed free radicals are reactive to pollutants in batik cual wastewater which are generally composed of various organic compounds. Free radicals will attack organic compounds in batik cual wastewater, thus the decolorization process occurs. The radical formation in the Fenton mechanism occurs in a very complex process. However, the simple explanation for the reaction is proposed by the Haber-Weiss through the reaction (Kremer, 1999);

$$
\begin{gathered}
\mathrm{Fe}^{2+}+\mathrm{H}_{2} \mathrm{O}_{2} \rightarrow \mathrm{Fe}^{3+}+\mathrm{HO}^{\bullet}+\mathrm{OH}^{-} \\
\mathrm{Fe}^{3+}+\mathrm{H}_{2} \mathrm{O}_{2} \rightarrow \mathrm{Fe}^{2+}+\mathrm{HO}_{2}^{-}+\mathrm{H}^{+}
\end{gathered}
$$

The net effect of this chemical reaction is that $\mathrm{H}_{2} \mathrm{O}_{2}$ is disproportionation to form two 
different oxygen-radical species with water as a by-product,

$$
2 \mathrm{H}_{2} \mathrm{O}_{2} \rightarrow \mathrm{HO}^{\bullet}+\mathrm{HO}_{2}^{\bullet}+\mathrm{H}_{2} \mathrm{O}
$$

In the Fenton reaction, there is a conversion process of $\mathrm{Fe}^{2+}$ ion (ferrous ion) to $\mathrm{Fe}^{3+}$ (ferric ion) and vice versa when the iron ion reacts to $\mathrm{H}_{2} \mathrm{O}_{2}$. Each phase produces radicals that play a role in the degradation process of pollutants in wastewater. Also, iron in the Fenton reaction can act as a catalyst in the hydroxyl formation process. Schematically, the conversion cycle of ferrous ion to ferric ion in the presence of hydrogen peroxide is shown in Figure 4.

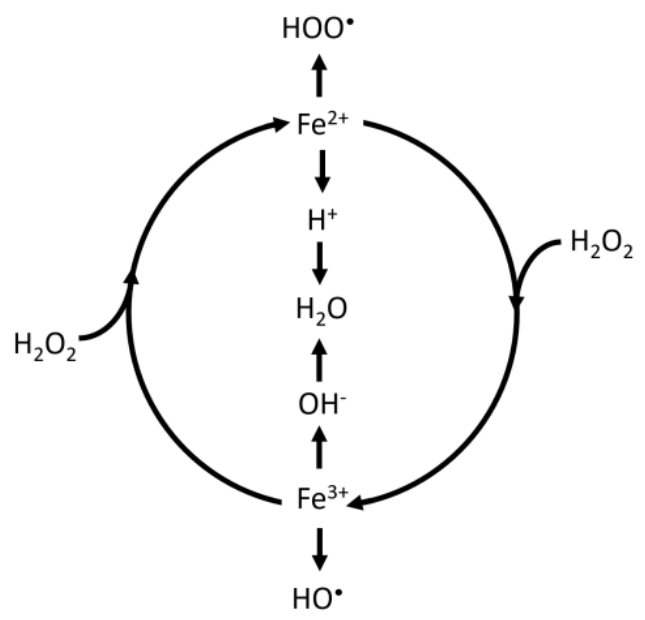

Figure 4. The Conversion Cycle of Ferrous Ion to Ferric Ion in Fenton Reaction

During the measurement process using a UV-Vis spectrophotometer, the highest absorbance peaks for all standard batik cual wastewater in various concentrations occurring at a wavelength of $699 \mathrm{~nm}$. Therefore, based on the Lambert-Berr law, there is a linear relationship between absorbance $(A)$, concentration $(c)$, molar absorption coefficient $(\varepsilon)$, and the optical length path of the solution $(l)$ (Nandiyanto et al., 2018):

$$
A=c \varepsilon l
$$

Then, a linear relationship between absorbance and concentration of batik cual wastewater is shown in Figure 5. The color concentration of the wastewater with absorbance at wavelength $699 \mathrm{~nm}$ fulfills the linear relationship that satisfies $y=0.0168 x+0.0123$, where $x$ is the wastewater color concentration, and $y$ is the absorbance value. The coefficient of the linear equation is excellent, i.e., $R^{2}=0.9975$. Thus, the calibration curve can be used to measure the color concentration of wastewater in this study.

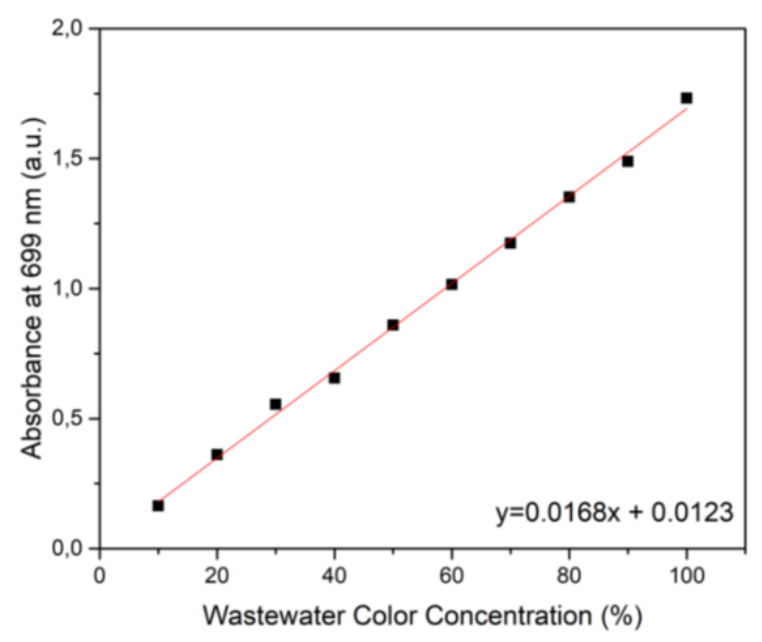

Figure 5. UV-Vis Spectrophotometer Calibration Curve to Detect the Color Concentration of Wastewater

The results of absorbance value of batik cual wastewater using the Fenton mechanism are shown in Table 1. Through the absorbance value, the color concentration value of the waste can be determined according to the calibration curve in Figure 5. The calculations show that the waste color concentration has decreased significantly after the Fenton mechanism was performed. The color concentration value of wastewater after the Fenton mechanism ranged from $6.78 \%$ to $2.20 \%$. The $0,5 \mathrm{gr}$ of $\mathrm{FeSO}_{4} .7 \mathrm{H}_{2} \mathrm{O}$ can reduce the color concentration of the wastewater by $2.20 \%$. It is in line with the results of the batik cual wastewater shown in Figure 3 that the resulted wastewater was more transparent than the raw wastewater. 
Table 1. The Absorbance Value Measurement and the Color Concentration value Calculation of the Wastewater

\begin{tabular}{ccc}
\hline $\begin{array}{c}\mathrm{FeSO}_{4} .7 \mathrm{H}_{2} \mathrm{O} \\
(\mathrm{gr})\end{array}$ & $\begin{array}{c}\text { Absorbance } \\
\text { (a.u) }\end{array}$ & $\begin{array}{c}\text { Wastewater Color } \\
\text { Concentration (\%) }\end{array}$ \\
\hline 0.1 & 0.072 & 3.69 \\
0.2 & 0.115 & 6.24 \\
0.3 & 0.124 & 6.78 \\
0.4 & 0.051 & 2.44 \\
0.5 & 0.047 & 2.20 \\
\hline
\end{tabular}

The Fenton method can reduce up to $97.8 \%$ of the batik cual wastewater's color. With the similar dosage of $\mathrm{H}_{2} \mathrm{O}_{2}$, the degradation effectiveness was higher than the degradation of a single dye i.e. methylene blue as conducted by Liu et al. (2013). In her research, Liu used $10 \mathrm{mg} / \mathrm{liter}$ of $\mathrm{H}_{2} \mathrm{O}_{2}$ of methylene blue solution resulted in the effectiveness of 93.1\% (Liu et al., 2013). This research used a higher dose of $\mathrm{FeSO}_{4} .7 \mathrm{H}_{2} \mathrm{O}$. The higher amount of FeSO $4.7 \mathrm{H}_{2} \mathrm{O}$ concentration increases $\mathrm{Fe}^{2+}$ which acts as a catalyst to decompose $\mathrm{H}_{2} \mathrm{O}_{2}$ and produce hydroxyl radicals. Also, $\mathrm{Fe}^{2+}$ or $\mathrm{Fe}^{3+}$ ion can serve as a coagulant agent. Thus, they may bind the color pollutant molecules of batik cual wastewater, both in raw pollutant and after the oxidation process (Setyaningtyas et al., 2019). However, when the amount of $\mathrm{FeSO}_{4} .7 \mathrm{H}_{2} \mathrm{O}$ catalyst is sufficient, the addition of more catalyst does not have a significant effect due to the limited amount of $\mathrm{H}_{2} \mathrm{O}_{2}$.

Figure 6 shows the results of COD measurements from batik cual wastewater after the application of Fenton mechanism. The Fenton mechanism is effective in reducing the COD value of the batik cual wastewater. Initially, the wastewater's COD value was $104 \mathrm{mg} / \mathrm{L}$. Then, it decreased to $24.7 \mathrm{mg} / \mathrm{L}$ after the Fenton mechanism was applied. Also, the higher amount of $\mathrm{FeSO}_{4} .7 \mathrm{H}_{2} \mathrm{O}$ used in the Fenton mechanism effectively reduced the COD levels. It occurred because more ferrous ions can generate hydroxyl radicals. Compared to hydroperoxyl radicals generated by ferric ions, hydroxyl radicals are more aggressive in destroying organic pollutants. The conversion of ferrous ions to ferric ions (and vice versa) increased the process reaction time. Thus, the high amount of $\mathrm{FeSO}_{4} .7 \mathrm{H}_{2} \mathrm{O}$ as a catalyst will accelerate the degradation of pollutants in batik cual wastewater.

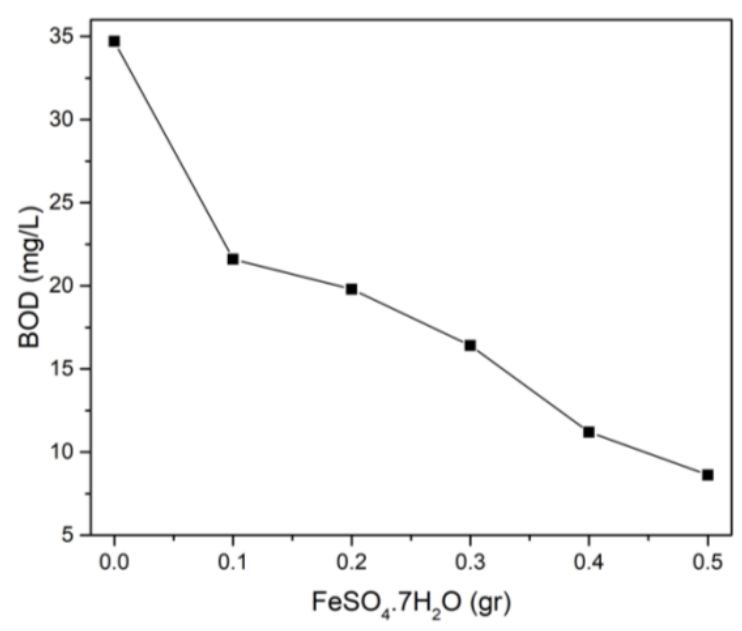

Figure 6. Relationship between the COD removal of batik cual wastewater and the amount of $\mathrm{FeSO}_{4} \cdot 7 \mathrm{H}_{2} \mathrm{O}$ in the Fenton mechanism

Compared to the other methods of AOPs, such as $\mathrm{UV}, \mathrm{UV} / \mathrm{Fe}^{2+}$, and $\mathrm{UV} / \mathrm{H}_{2} \mathrm{O}_{2}$, the Fenton $\left(\mathrm{Fe}^{2+} / \mathrm{H}_{2} \mathrm{O}_{2}\right)$ method is the most effective to degrade COD in textile wastewater. The effectiveness is determined by the ratio of COD degraded to the electrical energy needs. The Fenton method does not require electrical energy to work, but it can degrade COD around 80\% (Buthiyappan \& Abdul Raman, 2019). In this research, the effectiveness of COD degradation reached $79.3 \%$. In several other studies, it was also stated that UV radiation can increase the Fenton method's effectiveness in degrading COD (GilPavas et al., 2017; Pérez et al., 2002). The photo-Fenton method is considered more effective because of the continuous generation of reactive oxygen species, especially hydroxyl radicals.

Besides COD, Figure 7 presents the BOD levels in the batik cual wastewaters. There was a BOD decrease due to the Fenton mechanism. Initially, the raw wastewater's BOD value was $35 \mathrm{mg} / \mathrm{L}$. After the application of Fenton mechanism, the value decreased to $8.6 \mathrm{mg} / \mathrm{L}$. There was an increase in the organic matter's oxidation (related to 
aspects of biological oxygen) by radicals produced in the Fenton mechanism.

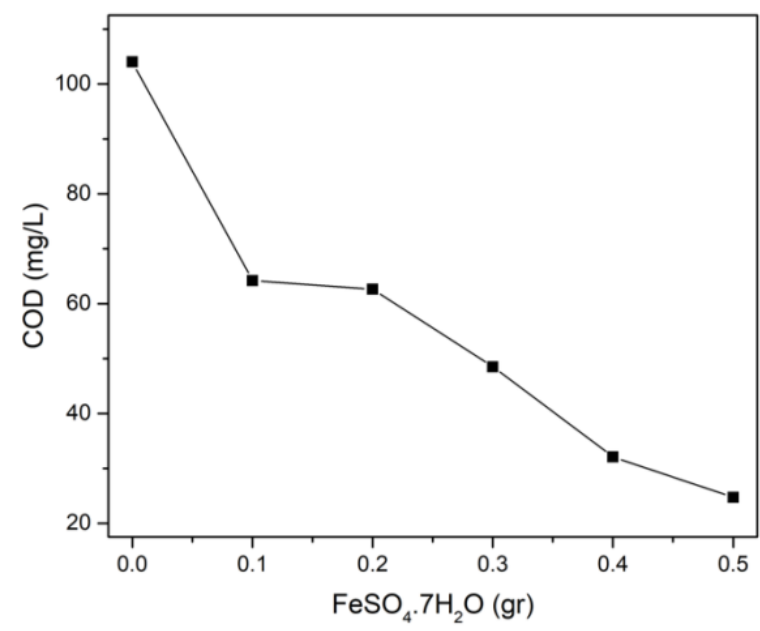

Figure 7. The Relationship between the BOD Removal and the amount of $\mathrm{FeSO}_{4} .7 \mathrm{H}_{2} \mathrm{O}$ in the Fenton Mechanism

By definition, COD is related to the amount of oxygen needed to break down all organic material contained in a liquid. Meanwhile, BOD is related to measuring the amount of oxygen required by microorganisms to decompose organic matter in aerobic conditions (readily decomposable organic matter). Therefore, the difference between COD and BOD provides information on the amount of organic matter that is difficult to decompose in wastewater (Atima, 2015). To observe the amount of non-biodegradable organic matter remaining in the waste after the Fenton mechanism, the researchers calculated the difference between COD and BOD as shown in Figure 8. The Fenton mechanism effectively reduced the amount of difficult to decompose organic material. The greater the use of $\mathrm{FeSO}_{4} .7 \mathrm{H}_{2} \mathrm{O}$, the smaller the difference between COD and BOD will be which indicates that the amount of the difficult to decompose organic matter remaining in the wastewater is low.

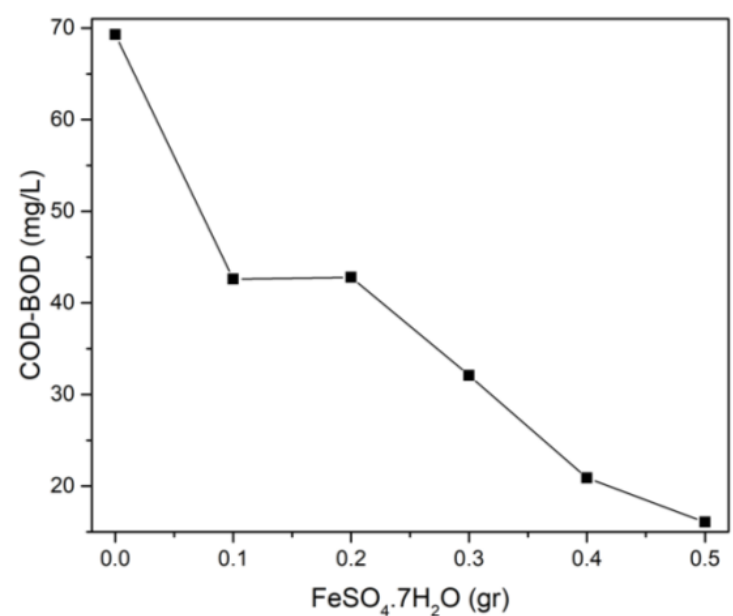

Figure 8. The Relationship between $\mathrm{COD}$ and $\mathrm{BOD}$ with the Amount of $\mathrm{FeSO}_{4} \cdot 7 \mathrm{H}_{2} \mathrm{O}$ in the Fenton Mechanism

\section{CONCLUSION AND SUGGESTION}

Without any processing, the batik cual wastewater has a very thick color. The Fenton mechanism helps decolorizing the wastewater. Through the Fenton mechanism, batik cual wastewater became significantly more transparent. Quantitatively, the color removal efficiency reached $97.8 \%$. The Fenton mechanism also reduced the COD and BOD levels in batik cual wastewater. The efficiency of COD removal reached $76.3 \%$, while BOD removal efficiency reached $75.2 \%$. Besides, the Fenton mechanism degraded difficult to decompose organic matter. The organic pollutants in batik cual wastewater was reduced by the Fenton mechanism because the ferrous ions from $\mathrm{FeSO}_{4} .7 \mathrm{H}_{2} \mathrm{O}$ can generate hydroxyl radicals that damage pollutant compounds. The more $\mathrm{FeSO}_{4} .7 \mathrm{H}_{2} \mathrm{O}$ added to the wastewater, the more effective the Fenton treatment will be. In further research, it is interesting to integrate the batik cual wastewater treatment method through the Fenton mechanism with other methods such as filtration and other AOPs methods to reduce the use of $\mathrm{FeSO}_{4} .7 \mathrm{H}_{2} \mathrm{O}$ catalyst. 


\section{ACKNOWLEDGMENT}

This research was funded by the Institute for Research and Community Services Universitas Bangka Belitung (LPPM-UBB) through Penelitian Unggulan scheme in 2020 (No. 192/UN50.11/PP/2020).

\section{REFERENCES}

Atima, W. (2015). BOD dan COD sebagai parameter pencemaran air dan baku mutu air limbah. Jurnal Biology Science \& Education, 4(1), 83-93.

Ayan, S., Furqon, C., \& Sultan, M. A. (2018). Business model canvas analysis on cual weaving industry. The International Journal of Business Review (The Jobs Review), 1(2), 129-136. https://doi.org/10.17509/tjr.v1i2.14108

Babaei, A. A., Kakavandi, B., Rafiee, M., Kalantarhormizi, F., Purkaram, I., Ahmadi, E., \& Esmaeili, S. (2017). Comparative treatment of textile wastewater by adsorption, Fenton, UVFenton and US-Fenton using magnetic nanoparticles-functionalized carbon (MNPs@C). Journal of Industrial and Engineering Chemistry, 56(July 2017), 163-174.

https://doi.org/10.1016/j.jiec.2017.07.0 09

Bhatia, D., Sharma, N. R., Singh, J., \& Kanwar, R. S. (2017). Biological methods for textile dye removal from wastewater: A review. Critical Reviews in Environmental Science and Technology, 47(19), 1836-1876. https://doi.org/10.1080/10643389.2017. 1393263

Burakov, A. E., Galunin, E. V., Burakova, I. V., Kucherova, A. E., Agarwal, S., Tkachev, A. G., \& Gupta, V. K. (2018). Adsorption of heavy metals on conventional and nanostructured materials for wastewater treatment purposes: A review. Ecotoxicology and Environmental Safety, 148(2), 702-712. https://doi.org/10.1016/j.ecoenv.2017.1 1.034

Buthiyappan, A., \& Abdul Raman, A. A.
(2019). Energy intensified integrated advanced oxidation technology for the treatment of recalcitrant industrial wastewater. Journal of Cleaner Production, 6(30), 1025-1040. https://doi.org/10.1016/j.jclepro.2018.0 9.234

Buthiyappan, A., Abdul Raman, A. A., \& Daud, W. M. A. W. (2016). Development of an advanced chemical oxidation wastewater treatment system for the batik industry in Malaysia. RSC Advances, 6(30), 25222-25241. https://doi.org/10.1039/c5ra26775g

Crini, G., \& Lichtfouse, E. (2019). Advantages and disadvantages of techniques used for wastewater treatment. Environmental Chemistry Letters, 17(1), 145-155. https://doi.org/10.1007/s10311-0180785-9

Dalvand, A., Ehrampoush, M. H., Ghaneian, M. T., Mokhtari, M., Ebrahimi, A. A., Ahmadi, R. M., \& Mahvi, A. H. (2017). Application of chemical coagulation process for direct dye removal from textile wastewater. Journal of Environmental Health and Sustainable Development, 2(3), 333-339.

Damayanti, I. R., \& Ferdiana, F. (2020). The role of online media communication in increasing tourism promotion in bangka regency. KnE Social Sciences, 2020, 910-923.

https://doi.org/10.18502/kss.v4i14.794 7

Galih, V., Putra, V., Purnomosari, E., \& Mohamad, J. N. (2020). Developing heat rate and heat capacity measurement instruments of textile waste solution in the textile dyeing process. Jurnal Ilmiah Pendidikan Fisika Al-Biruni 9(2), 323338.

https://doi.org/10.24042/jipfalbiruni.v9 i2.5951

Ghernaout, D., Elboughdiri, N., \& Ghareba, S. (2020). Fenton technology for wastewater treatment: Dares and trends. OALib, 07(01), 1-26. 
https://doi.org/10.4236/oalib.1106045

Gilja, V., Novaković, K., Travas-Sejdic, J.,

Hrnjak-Murgić, Z., Roković, M. K., \&

Žic, M. (2017). Stability and synergistic

effect of polyaniline/TiO2

photocatalysts in degradation of Azo

dye in wastewater. Nanomaterials, $7(12)$,

412.

https://doi.org/10.3390/nano7120412

GilPavas, E., Dobrosz-Gómez, I., \& GómezGarcía, M. Á. (2017). Coagulationflocculation sequential with fenton or photo-fenton processes as an alternative for the industrial textile wastewater treatment. Journal of Environmental Management, 191, 189-197. https://doi.org/10.1016/j.jenvman.2017. 01.015

GilPavas, E., Dobrosz-Gómez, I., \& GómezGarcía, M. Á. (2018). Optimization of sequential chemical coagulation electro-oxidation process for the treatment of an industrial textile wastewater. Journal of Water Process Engineering, 22(2), 73-79. https://doi.org/10.1016/j.jwpe.2018.01. 005

Guo, Y., Xue, Q., Zhang, H., Wang, N., Chang, S., Wang, H., Pang, H., \& Chen, H. (2018). Treatment of real benzene dye intermediates wastewater by the Fenton method: Characteristics and multi-response optimization. RSC Advances, $\quad 8(1), \quad 80-90$. https://doi.org/10.1039/c7ra09404c

Gusa, R. F., Sari, D. N., Afriani, F., Sunanda, W., \& Tiandho, Y. (2020). Effect of electrode numbers in electrocoagulation of Batik Cual wastewater: Analysis on water quality and energy used. IOP Conference Series: Earth and Environmental Science, 599(1), 1-5. https://doi.org/10.1088/17551315/599/1/012061

Hassaan, M. A., \& Nemr, A. E. (2017). Advanced oxidation processes for textile wastewater treatment. International Journal of Photochemistry and Photobiology, 2(5),
85-93. https://doi.org/10.1155/2013/683682

Khalik, W. F., Ho, L. N., Ong, S. A., Voon, C. H., Wong, Y. S., Yusuf, S. Y., Yusoff, N. A., \& Lee, S. L. (2018). Enhancement of simultaneous batik wastewater treatment and electricity generation in photocatalytic fuel cell. Environmental Science and Pollution Research, 25(35), 35164-35175. https://doi.org/10.1007/s11356-0183414-z

Khamparia, S., \& Jaspal, D. K. (2017). Adsorption in combination with ozonation for the treatment of textile waste water: a critical review. Frontiers of Environmental Science and Engineering, 11(1), 1-18. https://doi.org/10.1007/s11783-0170899-5

Kremer, M. L. (1999). Mechanism of the Fenton reaction. Evidence for a new intermediate. Physical Chemistry Chemical Physics, 1(15), 3595-3605. https://doi.org/10.1039/a903915e

Lestari, S., \& Windyartini, D. S. (2020). Application of sargassum cinereum and rhizobacteria as biosorbent $\mathrm{zn}$ in batik wastewater. Journal of Hunan University (Natural Sciences), 47(11), 15-21.

Liu, S. T., Huang, J., Ye, Y., Zhang, A. B., Pan, L., \& Chen, X. G. (2013). Microwave enhanced fenton process for the removal of methylene blue from aqueous solution. Chemical Engineering Journal, 215-216, 586590.

https://doi.org/10.1016/j.cej.2012.11.00 3

Malvestiti, J. A., Fagnani, E., Simão, D., \& Dantas, R. F. (2019). Optimization of $\mathrm{UV} / \mathrm{H} 2 \mathrm{O} 2$ and ozone wastewater treatment by the experimental design methodology. Environmental Technology (United Kingdom), 40(15), 1910-1922. https://doi.org/10.1080/09593330.2018. 1432698 
Naje, A. S., Chelliapan, S., Zakaria, Z., Ajeel, M. A., \& Alaba, P. A. (2017). A review of electrocoagulation technology for the treatment of textile wastewater. Reviews in Chemical Engineering, 33(3), 263-292. https://doi.org/10.1515/revce-20160019

Nandiyanto, A. B. D., Zaen, R., Oktiani, R., Abdullah, A. G., \& Riza, L. S. (2018). A simple, rapid analysis, portable, lowcost, and Arduino-based spectrophotometer with white LED as a light source for analyzing solution concentration. Telkomnika (Telecommunication Computing Electronics and Control), 16(2), 580585.

https://doi.org/10.12928/TELKOMNIK A.v16i2.7159

Paździor, K., Bilińska, L., \& Ledakowicz, S. (2019). A review of the existing and emerging technologies in the combination of AOPs and biological processes in industrial textile wastewater treatment. Chemical Engineering Journal, 375(22), 120597. https://doi.org/10.1016/j.cej.2018.12.05 7

Pérez, M., Torrades, F., Domènech, X., \& Peral, J. (2002). Fenton and photoFenton oxidation of textile effluents. Water Research, 36(11), 2703-2710. https://doi.org/10.1016/S00431354(01)00506-1

Piaskowski, K., Świderska-Dąbrowska, R., \& Zarzycki, P. K. (2018). Dye removal from water and wastewater using various physical, chemical, and biological processes. Journal of AOAC International, 101(5), 1371-1384. https://doi.org/10.5740/jaoacint.180051

Qin, Q., Liu, Y., Li, X., Sun, T., \& Xu, Y. (2018). Enhanced heterogeneous Fenton-like degradation of methylene blue by reduced $\mathrm{CuFe} 2 \mathrm{O} 4$. $R S C$ Advances, $\quad$ 8(2), 1071-1077. https://doi.org/10.1039/c7ra12488k
Rahmadyanti, E., \& Febriyanti, C. P. (2020). Feasibility of constructed wetland using coagulation flocculation technology in batik wastewater treatment. Journal of Ecological Engineering, 21(6), 67-77. https://doi.org/10.12911/22998993/123 253

Kumar, P. S., Joshiba, G. J., Femina, C. C., Varshini, P., Priyadharshini, S., Karthick, M. S. A., \& Jothirani, R. (2019). A critical review on recent developments in the low-cost adsorption of dyes from wastewater. Desalination and Water Treatment, 172, 395-416. https://doi.org/10.5004/dwt.2019.24613 Setyaningtyas, T., Riyani, K., Handayani, S. N., \& Firdharini, C. (2019). Degradation of Congo Red in batik wastewater using fenton reagent under visible rays. IOP Conference Series: Materials Science and Engineering, 509(1), 012027. https://doi.org/10.1088/1757899X/509/1/012027

Shoukat, R., Khan, S. J., \& Jamal, Y. (2019). Hybrid anaerobic-aerobic biological treatment for real textile wastewater. Journal of Water Process Engineering, 29(3), 100804. https://doi.org/10.1016/j.jwpe.2019.100 804

Tomohardjo, I. S., Tresnawati, Y., \& Yulista, Y. (2018). Communication pattern to develop the spirit of creative economy and local wisdom value in betawi batik craftsmen Terogong Jakarta and cual batik craftsmen Pangkal Pinang Bangka Belitung Island. Proceeding The 1st International Conference on Social Sciences, 1(1), 279-290. https://jurnal.umj.ac.id/index.php/icoss/ article/view/2334

Zhang, H., Li, P., Wang, Z., Cui, W. W., Zhang, Y., Zhang, Y., Zheng, S., \& Zheng, Y. (2018). Sustainable Disposal of $\mathrm{Cr}(\mathrm{VI})$ : Adsorption-Reduction Strategy for Treating Textile Wastewaters with Amino- 
Functionalized Boehmite Hazardous Solid Wastes. ACS Sustainable Chemistry and Engineering, 6(5), 6811-6819.

https://doi.org/10.1021/acssuschemeng. $8 \mathrm{~b} 00640$

Zhang, M. H., Dong, H., Zhao, L., Wang, D. X., \& Meng, D. (2019). A review on
Fenton process for organic wastewater treatment based on optimization perspective. Science of the Total Environment, 670, 110-121. https://doi.org/10.1016/j.scitotenv.2019 .03 .180 